\title{
Long term changes in forest cover and land use of Similipal Biosphere Reserve of India using satellite remote sensing data
}

\author{
K R L Saranya and C Sudhakar RedDY* \\ Forestry 83 Ecology Group, National Remote Sensing Centre, ISRO, Balanagar, Hyderabad 500 037, India. \\ ${ }^{*}$ Corresponding author. e-mail: drsudhakarreddy@gmail.com
}

The spatial changes in forest cover of Similipal biosphere reserve, Odisha, India over eight decades (19302012) has been quantified by using multi-temporal data from different sources. Over the period, the forest cover reduced by $970.8 \mathrm{~km}^{2}$ (23.6\% of the total forest), and most significantly during the period, 1930-1975. Human-induced activities like conversion of forest land for agriculture, construction of dams and mining activities have been identified as major drivers of deforestation. Spatial analysis indicates that 399 grids $(1$ grid $=1 \times 1 \mathrm{~km}$ ) have undergone large-scale changes in forest cover (>75 ha) during 1930-1975, while only 3 grids have shown $>75$ ha loss during 1975-1990. Annual net rate of deforestation was 0.58 during 1930-1975, which has been reduced substantially during 1975-1990 (0.04). Annual gross rate of deforestation in 2006-2012 is indeed low (0.01) as compared to the national and global average. This study highlights the impact and effectiveness of conservation practices in minimizing the rate of deforestation and protecting the Similipal Biosphere Reserve.

\section{Introduction}

Forest is key natural resource that provides a wide variety of products and ecosystem services, receiving a global attention due to the increasing impact of anthropogenic activities (Le Quéré et al. 2009). Conservation of large natural forest landscapes is the most important task to fulfill global initiatives to protect forest biodiversity (SCBD 2001). Through commencement of UNESCO's Man and the Biosphere Program in the 1960s, biosphere reserves have been considered as strategic areas for conservation effectiveness (Chowdhury 2006; Schliep and Stoll-Kleemann 2010).

It is essential to have evidence of actual trends in natural forest cover for realistic conservation planning. The 'natural forest definition' has been indicated to become important in the REDD+ negotiations and conservation agencies (Romijn et al.
2013). The Forest Survey of India (FSI) defines forest cover as 'all lands more than one hectare in area, with a tree canopy density of more than $10 \%$, irrespective of ownership and legal status (FSI 2011). Thus, forest cover as reported by FSI does not make any distinction between natural or man-made tree cover. In this study, we have used natural forest definition to account the forest cover changes in Similipal Biosphere Reserve. In the present study, forest is defined as land spanning more than 1 ha, dominated with native tree species having a minimum stand height of $5 \mathrm{~m}$ with an over-storey canopy cover greater than $10 \%$.

Satellite remote sensing is the only feasible and cost effective technique to monitor land use and land cover conversions over large areas. Certain studies on deforestation in different protected areas all over the world were reported through remote sensing techniques. The study on Maya Biosphere

Keywords. Deforestation; conservation; biosphere reserve; satellite data; Similipal. 
Reserve in Gautemala has reported the deforestation (Sader et al. 2001). The study on Calakmul Biosphere Reserve of Mexico has recorded increased deforestation during 1987-1996 (Chowdhury 2006), while, Monarch Butterfly Biosphere Reserve in Mexico has undergone deforestation during 20032009 (Garcia 2012). Land cover change analysis in Upper Lusatia Biosphere Reserve of Germany reveals management effectiveness during 1992-2005 (Ohnesorge et al. 2013). The decadal time scale analysis for Similipal Biosphere Reserve of India addresses anthropogenic impact of fire on forest ecosystems (Saranya et al. 2014). The study carried out in Nilgiri Biosphere Reserve of India states a significant loss of forest cover during 1920-1973 and gradual decline in the period of 1973-1989 (Satish et al. 2014). Recent study provides nationwide comprehensive data for understanding chronological long term forest cover changes in India over last eight decades (Reddy et al. 2015). The study by Reddy et al. (2016) has provided an account of the extent, distribution and changes in forests covering the whole of Western Ghats. Overall loss in forests of Western Ghats was estimated as $33,579 \mathrm{~km}^{2}$ (35.3\% of the total forest) from 1920 to 2013. However, quantification of ecological degradation is still a challenging task.

Keeping in view of the above, the objective of the present study is to understand the spatial patterns of forest cover in Similipal Biosphere Reserve during 1930-2012.

\section{Study area}

Similipal is situated in Mayurbhanj district of Odisha and is the only biosphere reserve of the northern Eastern Ghats (figure 1). It lies between $21^{\circ} 28^{\prime}-22^{\circ} 15^{\prime} \mathrm{N}$ and $86^{\circ} 03^{\prime}-86^{\circ} 37^{\prime} \mathrm{E}$. The hills, with their innumerable crests and valleys interspersed with countless streams and rivers exhibit a great degree of topographic variation, ranging from 200 to $1165 \mathrm{~m}$ above sea level. The annual rainfall varies from 1200 to $2000 \mathrm{~mm}$. The temperature ranges from $9^{\circ}$ to $33.5^{\circ} \mathrm{C}$. There are 1276 species of vascular plants recorded including 60 species of ferns, 92 species of orchids and two gymnosperms in the area (Saxena and Brahmam 1989; Bahali et al. 1998). The Government of Odisha declared Similipal as a wildlife sanctuary in 1979 with an area of $2200 \mathrm{~km}^{2}$, and later in $1980,303 \mathrm{~km}^{2}$ of the sanctuary was proposed as a national park. Government of India declared Similipal as a biosphere reserve $\left(5569 \mathrm{~km}^{2}\right)$ on 22 June 1994 due to its rich biodiversity and natural heritage. Being one of the mega biodiversity zones of India, it was brought into the Man and Biosphere Programme of UNESCO in May 2009 (Palni et al. 2012).

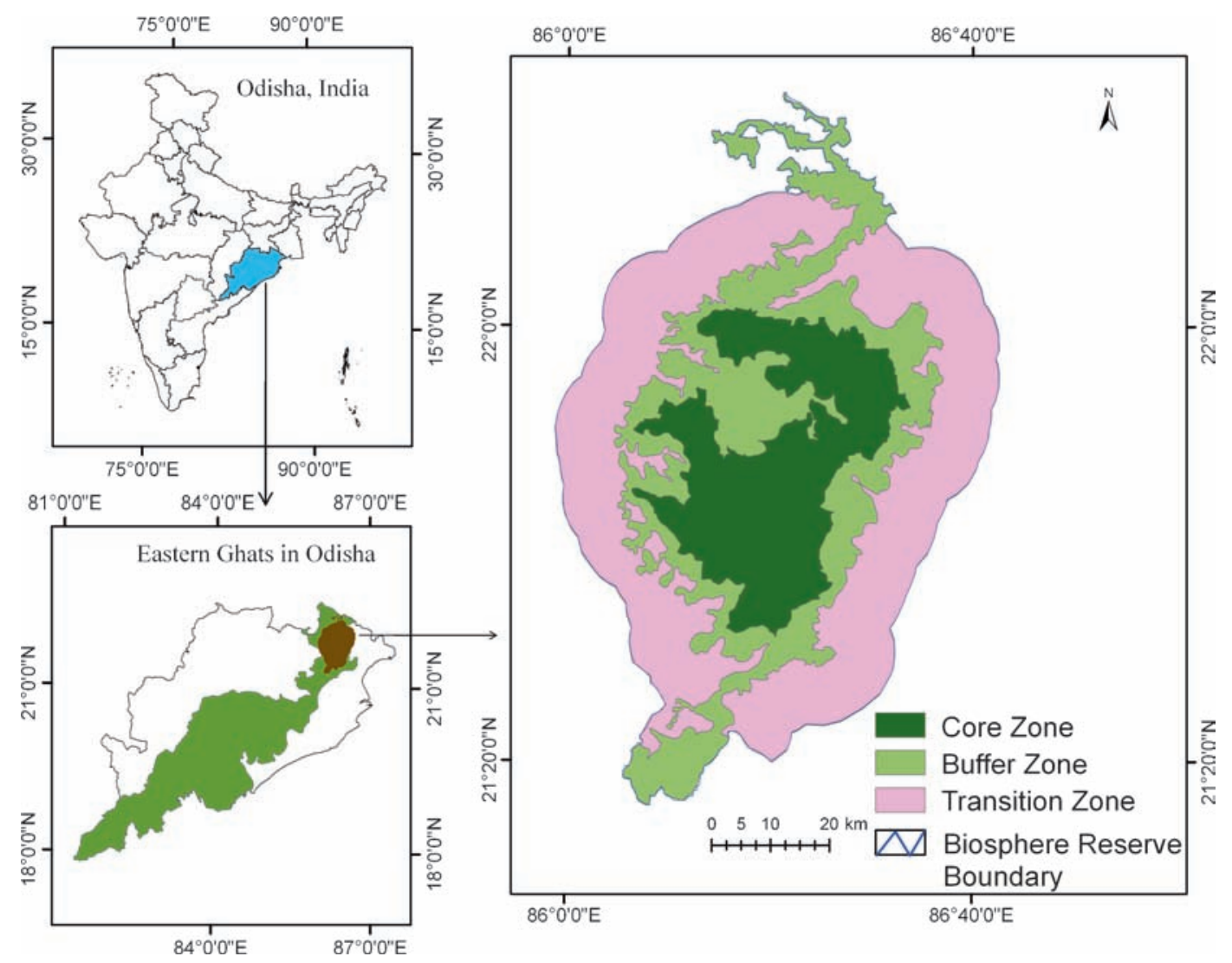

Figure 1. Map showing location and zones of Similipal Biosphere Reserve, Odisha, India. 


\section{Materials and methods}

\subsection{Data used}

To generate maps of forest cover, we have used Survey of India topographical maps and multi-temporal remote sensing data covering different periods, as and when these were available (table 1). Geometric correction of raw satellite data was done through first-order polynomial transformation fit based on ortho-rectified Landsat Thematic Mapper data (http://glcf.umiacs.umd.edu/) for reference. Radiometric normalization was carried out using 'Top of atmosphere correction' technique. The images were geo-referenced to the Universal Transverse Mercator (UTM) coordinate system and WGS84 datum. Re-sampling process was performed using a nearest neighbour algorithm. Image-to-image registration yielded a root-mean-square error of $<1$ pixels for all satellite data. The study area was extracted from the multiple satellite data scenes by image subset process. The boundary of biosphere reserve was obtained from the Ministry of Environment and Forest (MoEF) (Palni et al. 2012). Survey of India topographical maps of 1:50,000 scale were used as the reference.

\subsection{Forest cover and other land use mapping}

Multi-season satellite data pertaining to the months of December 2011, March 2011, March 2012 and May 2012 were used as the base for mapping of forests and land use features and included in the spatial database of recent period (2012). This has facilitated spatial framework for interpretation and updation of changes in the forest for other periods (1990, 1995, 2000, and 2006) and land use change of 1975 and 2012. Types of land use/land cover in the study area included forest, scrub, grasslands, agriculture, orchards, settlements, water, barren land and mining. Six major forest types were delineated in the study area, i.e., semi-evergreen, moist deciduous, dry deciduous, low level sal, high level sal (moist peninsular sal) and riparian forest. The land use/land cover maps of 1975 and 2012 were cross-tabulated for generating the trend and quantification of spatial change.

\subsection{Accuracy assessment}

Accuracy assessment has been performed from onsite collection of 293 samples from the ground during 2012 and 2013. Validations of maps for 1975, 1990, 1995, 2000, 2006 and 2012 were done based on visual assessment of satellite images and the temporal consistency of field samples. Overall accuracy and kappa coefficient of classified map (2012) was calculated as $92.28 \%$ and 0.90 , respectively.

\subsection{Rate of forest cover change}

The net and gross-rate of deforestation and afforestation has been estimated based on the change in forest cover. The annual rate of forest cover change was calculated based on compound interest formula (Puyravaud 2003).

$$
r=\frac{1}{\left(t_{2}-t_{1}\right)} \times \ln \frac{a_{2}}{a_{1}},
$$

where $r$ is the annual rate of change (percentage per year), $a_{1}$ and $a_{2}$ are the forest cover estimates at time $t_{1}$ and $t_{2}$, respectively.

\subsection{Spatial analysis of forest changes}

A grid cell of $1 \times 1 \mathrm{~km}$ was generated for time series analysis to understand the patterns in spatial distribution of forest cover (1930-2012). On each spatial data, the area covered by forest was calculated for any trend of change. Spatial extent of change was categorized across the five classes, i.e., $<10,10-25,25-50,>50-75$ and $>75$ ha.

\subsection{Analysis of primary forest and secondary forest}

The forest cover classes were categorized as primary old growth forest and secondary forests

Table 1. Details of spatial data used in the study.

\begin{tabular}{llcrc}
\hline Sl. no. & Data & Period & Scale/resolution & Source \\
\hline 1 & Survey of India Topographical & $1923-1937$ & $1: 250,000$ & U.S Army \\
& maps (NF45/6, NF45/10) & & & \\
2 & Landsat MSS & 1975 & $80 \mathrm{~m}$ & NASA \\
3 & Landsat TM & 1990 & $30 \mathrm{~m}$ & NASA \\
4 & IRS 1B LISS I & 1995 & $72.5 \mathrm{~m}$ & NASA \\
5 & Landsat ETM+ & 2000 & $30 \mathrm{~m}$ & NASA \\
6 & IRS P6 LISS III & 2006 & $23.5 \mathrm{~m}$ & ISRO \\
7 & IRS P6 LISS III & 2011 & $23.5 \mathrm{~m}$ & ISRO \\
8 & Resourcesat-2 LISS III & 2012 & $23.5 \mathrm{~m}$ & ISRO \\
\hline
\end{tabular}


using overlay analysis. Geospatial analysis considers woody vegetation re-growing on land that was largely cleared of its original forest cover as secondary forests.

\section{Results and discussion}

\subsection{Distribution and change of forest cover}

Distribution and changes in forest cover were analyzed using the area statistics derived from multitemporal classified maps (table 2). There was a significant loss in forest cover during 1930 to 1975 and the loss were considerably reduced during the period 1975-1990.

Table 2. Areal extent of forest cover distribution in zones of Similipal Biosphere Reserve $\left(\mathrm{km}^{2}\right)$.

\begin{tabular}{ccccc}
\hline Year & Core & Buffer & Transition & Area $\left(\mathrm{km}^{2}\right)$ \\
\hline 1930 & 1194.8 & 1546.2 & 1364.9 & 4105.8 \\
1975 & 1177.2 & 1410.0 & 572.4 & 3159.7 \\
1990 & 1176.7 & 1403.1 & 563.3 & 3143.1 \\
1995 & 1177.0 & 1402.2 & 563.8 & 3143.0 \\
2000 & 1176.5 & 1399.4 & 560.6 & 3136.6 \\
2006 & 1176.5 & 1399.9 & 559.1 & 3135.5 \\
2012 & 1176.5 & 1399.7 & 558.8 & 3135.0 \\
\hline
\end{tabular}
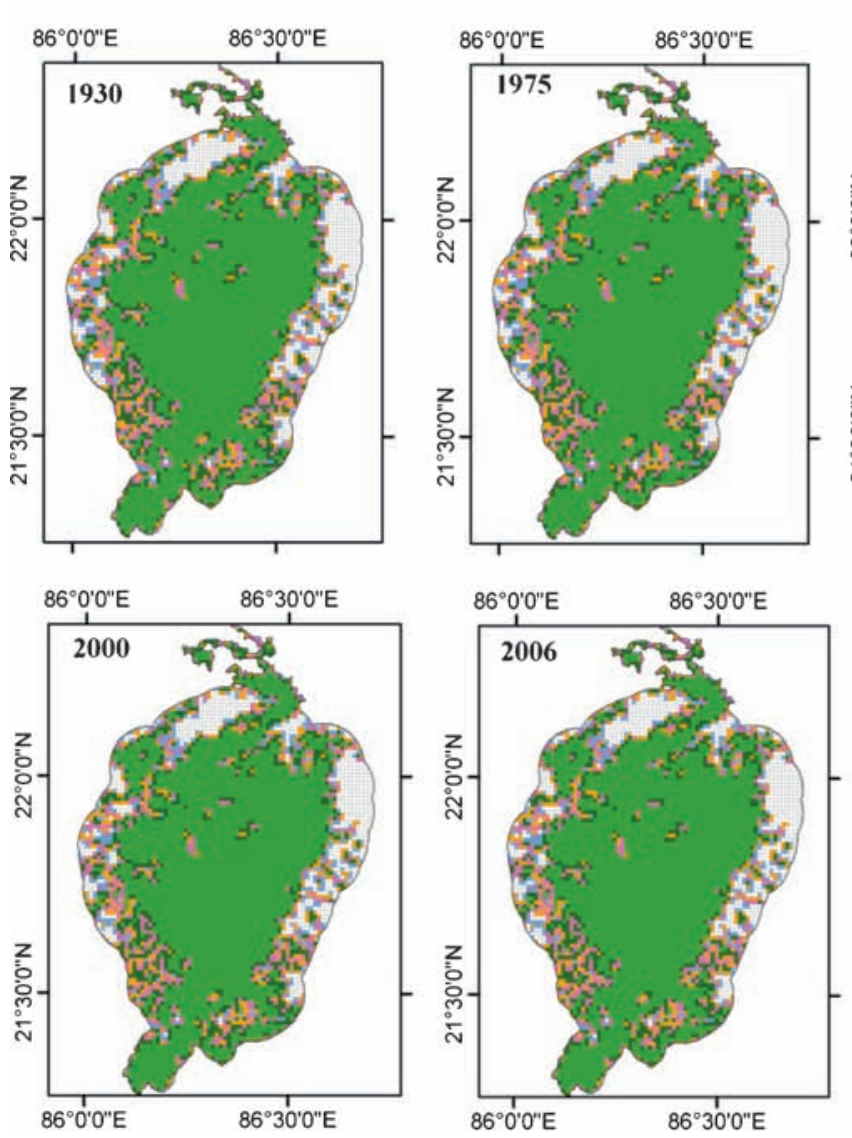

Total forest area of biosphere reserve was recorded as $4105.2 \mathrm{~km}^{2}$ (76.1\% of total geographical area) in 1930's period, while for the years 1975 and 1990, the forest cover account of 3159.7 and $3143.1 \mathrm{~km}^{2}$, respectively has been indicated. There was $23 \%\left(946.1 \mathrm{~km}^{2}\right)$ of reduction in the forest cover between 1930 and 1975. Within a period of 82 years (1930-2012), the forest cover decline was $970.8 \mathrm{~km}^{2}$ (23.6\% of the total forest). As elsewhere in the biosphere reserve, deforestation started mainly after the development of infrastructure, dam construction and intense population growth (Reddy et al. 2013).

\subsection{Grid-wise analysis of forest cover change}

The forest cover change maps for years 1930, 1975, 1990, 1995, 2000, 2006 and 2012 along with grid-wise forest cover and the time-series maps of periods 1930-1975, 1975-1990, 1990-2012 and 1930-2012 are shown in figures 2 and 3. Out of 5656 grids in the reserve, 5144 are full and 512 are partial grids. The number of forest grids distributed across the biosphere reserve from 1975 to 2012 is presented in figure 4 and table 3 . It is certain that the highest number of grids has undergone changes (loss in forest cover) during 1930-1975,
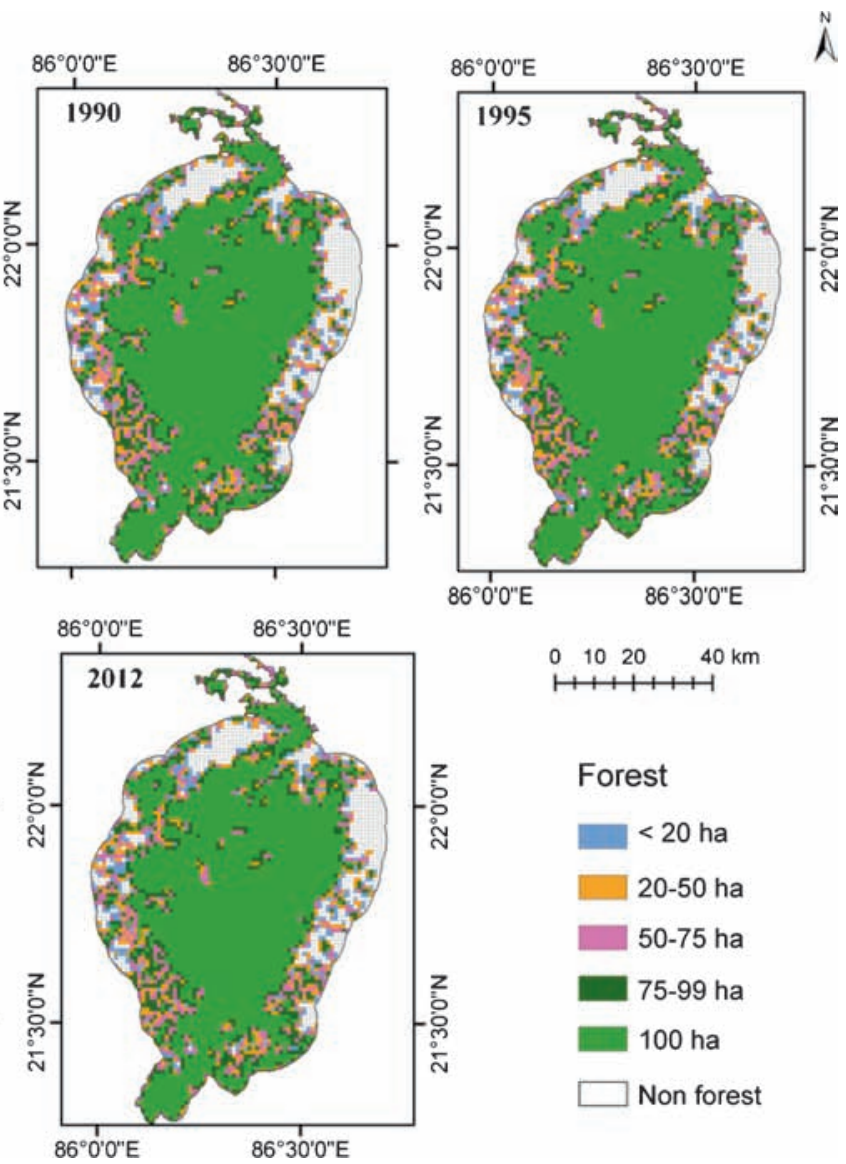

Forest

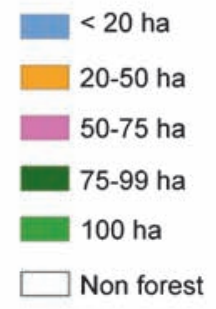

Figure 2. Spatial distribution of forest cover: 1930 to 2012. 

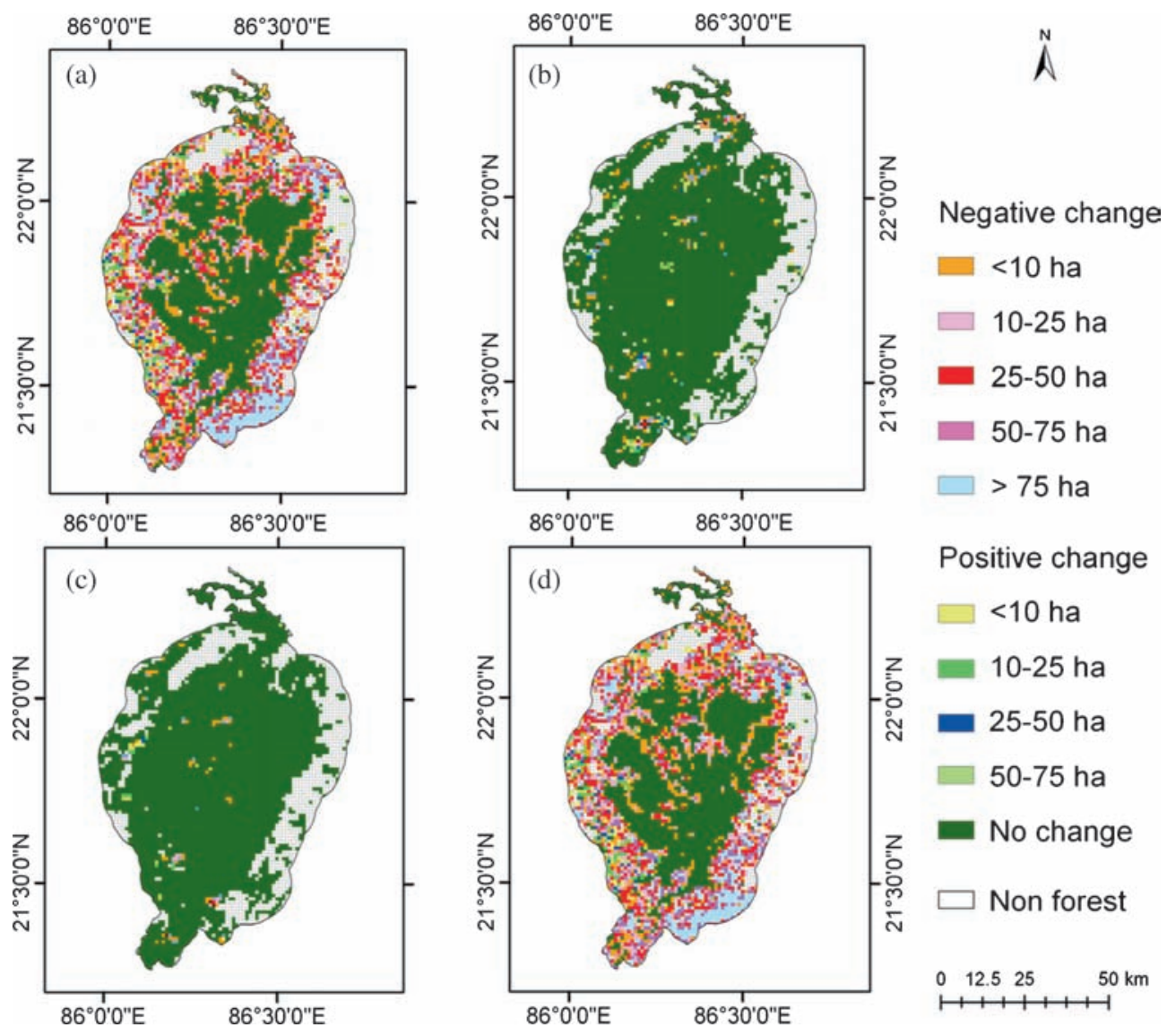

Positive change

$<10$ ha

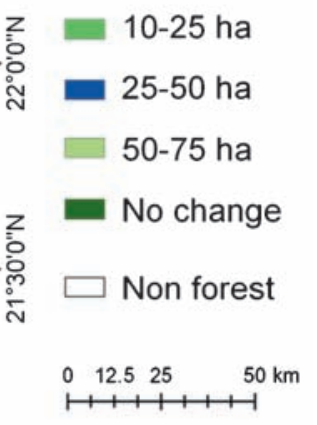

Figure 3. Spatial forest cover change: 1930-1975, 1975-1990, 1990-2012 and 1930-2012.

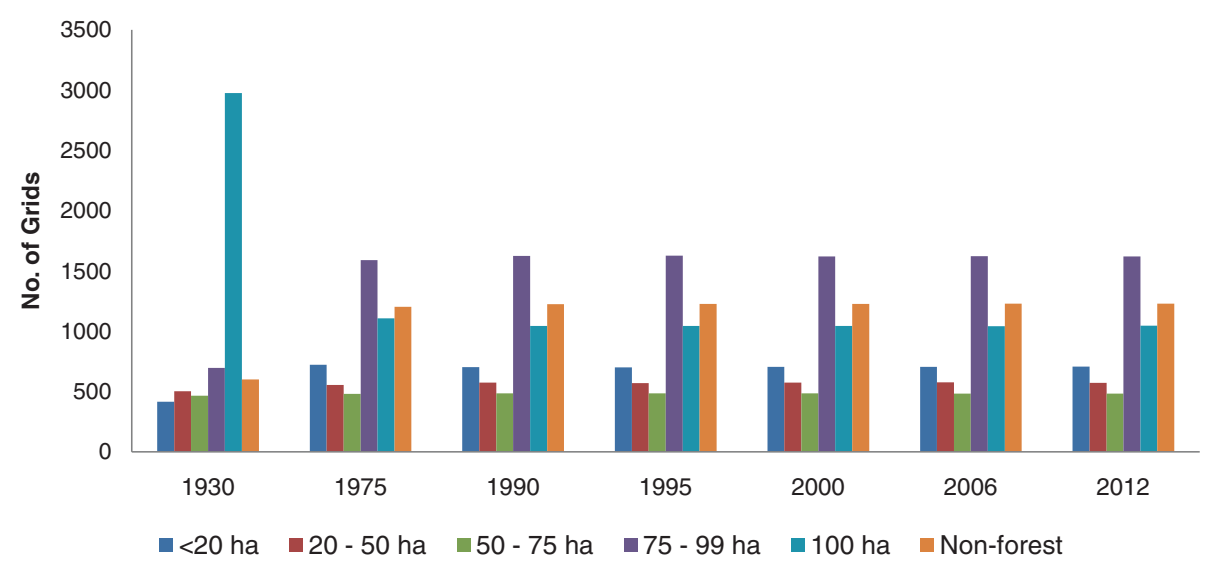

Figure 4. Distribution of forest and non forest grids across Similipal Biosphere Reserve from 1975 to 2012.

Table 3. Number of forest and non-forest grids distributed across Similipal Biosphere Reserve from 1975 to 2012.

\begin{tabular}{ccccccc}
\hline Year & $<20$ ha & $20-50$ ha & $50-75$ ha & $75-99$ ha & 100 ha & Non-forest \\
\hline 1930 & 415 & 503 & 465 & 696 & 2976 & 601 \\
1975 & 722 & 555 & 480 & 1590 & 1107 & 1202 \\
1990 & 703 & 574 & 485 & 1625 & 1045 & 1224 \\
1995 & 701 & 571 & 485 & 1628 & 1044 & 1227 \\
2000 & 705 & 574 & 486 & 1620 & 1044 & 1227 \\
2006 & 705 & 576 & 482 & 1622 & 1043 & 1228 \\
2012 & 706 & 572 & 482 & 1621 & 1046 & 1229 \\
\hline
\end{tabular}


Table 4. Analysis of grid-wise forest cover loss and gain in Similipal Biosphere Reserve.

\begin{tabular}{lcrcccr}
\hline Class & $1930-1975$ & $1975-1990$ & $1990-1995$ & $1995-2000$ & $2000-2006$ & $2006-2012$ \\
\hline Loss & & & & & & \\
$<10$ ha & 669 & 111 & 29 & 36 & 15 & 16 \\
$10-25$ ha & 639 & 47 & 10 & 11 & 2 & 4 \\
$25-50$ ha & 676 & 20 & 3 & 5 & 5 & 4 \\
$50-75$ ha & 400 & 8 & 1 & 3 & 0 & 0 \\
$>75$ ha & 399 & 3 & 0 & 1 & 0 & 0 \\
Total & 2783 & 189 & 43 & 56 & 22 & 24 \\
Gain & & & & & & \\
$<10$ ha & 181 & 60 & 21 & 18 & 9 & 13 \\
$10-25$ ha & 118 & 23 & 7 & 4 & 4 & 2 \\
$25-50$ ha & 46 & 11 & 4 & 0 & 1 & 2 \\
$50-75$ ha & 7 & 1 & 1 & 1 & 0 & 0 \\
$>75$ ha & 0 & 0 & 1 & 0 & 0 & 0 \\
Total & 352 & 95 & 34 & 23 & 14 & 17 \\
\hline
\end{tabular}

Table 5. Net rate of deforestation in Similipal Biosphere Reserve.

\begin{tabular}{lcccccccc}
\hline Sl. no. & T1/T2 & 1930 & 1975 & 1990 & 1995 & 2000 & 2006 & 2012 \\
\hline 1 & 1930 & - & 0.58 & 0.45 & 0.41 & 0.38 & 0.35 & 0.33 \\
2 & 1975 & - & - & 0.04 & 0.03 & 0.03 & 0.02 & 0.02 \\
3 & 1990 & - & - & - & 0.00 & 0.02 & 0.02 & 0.01 \\
4 & 1995 & - & - & - & - & 0.04 & 0.02 & 0.02 \\
5 & 2000 & - & - & - & - & - & 0.01 & 0.00 \\
6 & 2006 & - & - & - & - & - & - & 0.00 \\
\hline
\end{tabular}

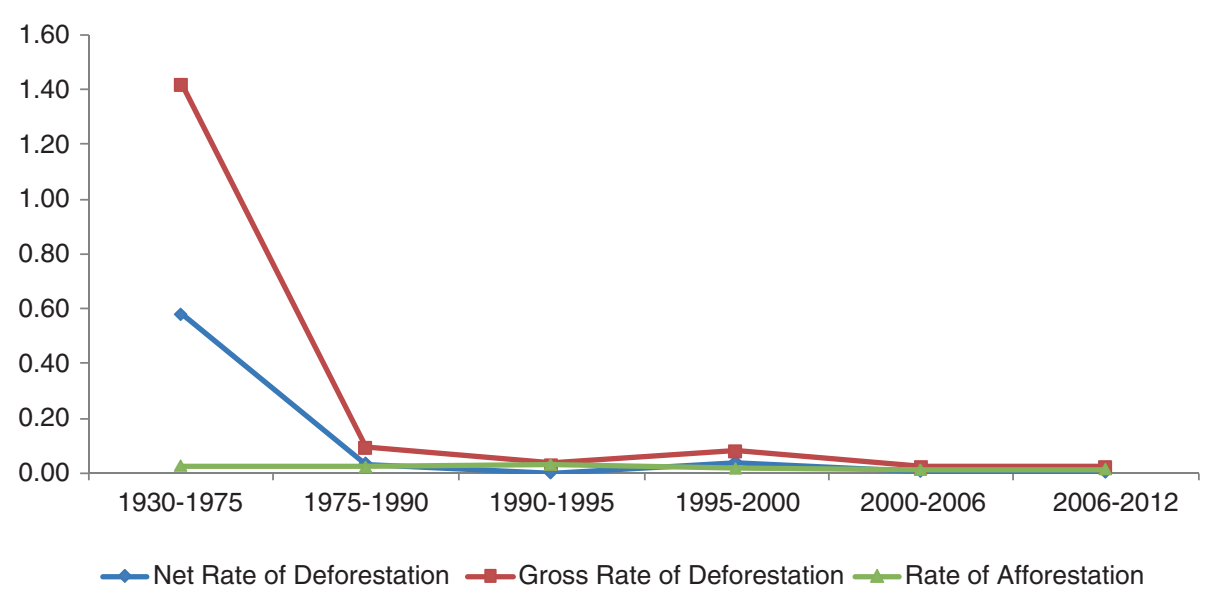

Figure 5. Graph showing net and gross rate of deforestation and afforestation in Similipal Biosphere Reserve.

which has been substantially reduced during 19751990 and more so during 1990-1995 period. A total of 88 grids have shown loss in forest cover during 1975-1995, while 127 grids have depicted loss in forest area during 1995-2006. The number of grids affected by deforestation during 2006-2012 was 24 (table 4). On the whole, 2431 grids have shown loss in forest cover during 1930-2012. The positive change (increase) in forest cover is $1.4 \mathrm{~km}^{2}$ during
1995-2000. During the period of 2000-2006, the gain in forest cover was $1.3 \mathrm{~km}^{2}$, covering 14 grids. During 2006-2012, the gain in forest cover was observed in 17 grids with an estimated area of $1.7 \mathrm{~km}^{2}$. Therefore, a natural regrowth and protection of the forest area has contributed to the increase of forest cover in the reserve, although a net forest cover loss of $0.5 \mathrm{~km}^{2}$ took place between the period 2006-2012. 


\subsection{Rate of deforestation and afforestation}

As Similipal was declared as Biosphere Reserve, the trend of deforestation was observed to be low during recent period. Gross rate of deforestation refers to total loss of forest cover. Net rate of deforestation considers afforested area, while accounting the loss of forest cover. A net rate of deforestation was most evident during the period 1930-1975 and 1975-1990, respectively (table 5). Annual net rate of deforestation in Similipal for the period of 1930 to 1975 was estimated at $0.58 \%$, followed by 0.04 for 1975-1990 (figure 5). The rate of afforestation was found to be $0.01 \%$ during the period of 1995-2000, 2000-2006 and 2006-2012 (table 6). The higher rates of gross deforestation during the period 1930-1975 and 1975-1990 were mostly

Table 6. Net and gross rate of deforestation and afforestation in Similipal Biosphere Reserve.

\begin{tabular}{lccc}
\hline Year & $\begin{array}{c}\text { Net rate of } \\
\text { deforestation }\end{array}$ & $\begin{array}{c}\text { Gross rate of } \\
\text { deforestation }\end{array}$ & $\begin{array}{c}\text { Rate of } \\
\text { afforestation }\end{array}$ \\
\hline $1930-1975$ & 0.58 & 1.42 & 0.03 \\
$1975-1990$ & 0.04 & 0.09 & 0.02 \\
$1990-1995$ & 0.00 & 0.03 & 0.03 \\
$1995-2000$ & 0.04 & 0.08 & 0.01 \\
$2000-2006$ & 0.01 & 0.02 & 0.01 \\
$2006-2012$ & 0.00 & 0.02 & 0.01 \\
\hline
\end{tabular}

Table 7. Net rate of deforestation in core, buffer and transition zones of Similipal Biosphere Reserve.

\begin{tabular}{lccc}
\hline Year & Core & Buffer & Transition \\
\hline $1930-1975$ & 0.03 & 0.20 & 1.93 \\
$1975-1990$ & 0.00 & 0.03 & 0.11 \\
$1990-1995$ & 0.00 & 0.01 & 0.00 \\
$1995-2000$ & 0.00 & 0.04 & 0.12 \\
$2000-2006$ & 0.00 & 0.00 & 0.05 \\
\hline
\end{tabular}

attributed to agricultural development and mining activities. The current estimates of gross deforestation in 2006-2012 (0.01\%) which is quite low as compared to national average $(0.43 \%)$ for $2009-2011$ (FSI 2011) and global average of $0.6 \%$ (Hansen et al. 2010). The decrease in the rate of gross deforestation could be attributed to the policies, natural regrowth of vegetation and afforestation/reforestation programmes taken up by management of biosphere reserve. Overall trend of annual net rate of deforestation has been regularly decreasing $0.34 \%$ during 1930-1975, 0.20\% during 1975-1995 and $0.03 \%$ during $1995-2010$. The net annual rate of deforestation across the zones of Similipal Biosphere Reserve was calculated and given in table 7 . The rate of deforestation was nil since 1975 in the core zone, which consists of the National Park (figure 6).

\subsection{Analysis of primary forest and secondary forest}

Primary forest has been estimated as $3032 \mathrm{~km}^{2}$ (96.7\% of geographical area) and secondary forest as $102.9 \mathrm{~km}^{2}(3.3 \%)$ in 2012 . Secondary forests developed naturally on land abandoned after cultivation and mining. Existence of old growth forests in Similipal Biosphere Reserve is a good indication to conserve interior and narrow niched species. Therefore, management of primary forest ecosystems may have positive consequences on native biodiversity (Gardner et al. 2009).

\subsection{Land use in deforested area}

The change drivers of deforestation include expansion of agriculture, settlements, mining, orchards, logging, and fuel wood extraction. Conversion of forest to agricultural land was estimated at $593.2 \mathrm{~km}^{2}$, and the other classes like grasslands, barren land and mining as 3.2, 0.2 and 1.4 $\mathrm{km}^{2}$, respectively during 1930-2012 (table 8). The second-most anthropogenic threat is conversion of

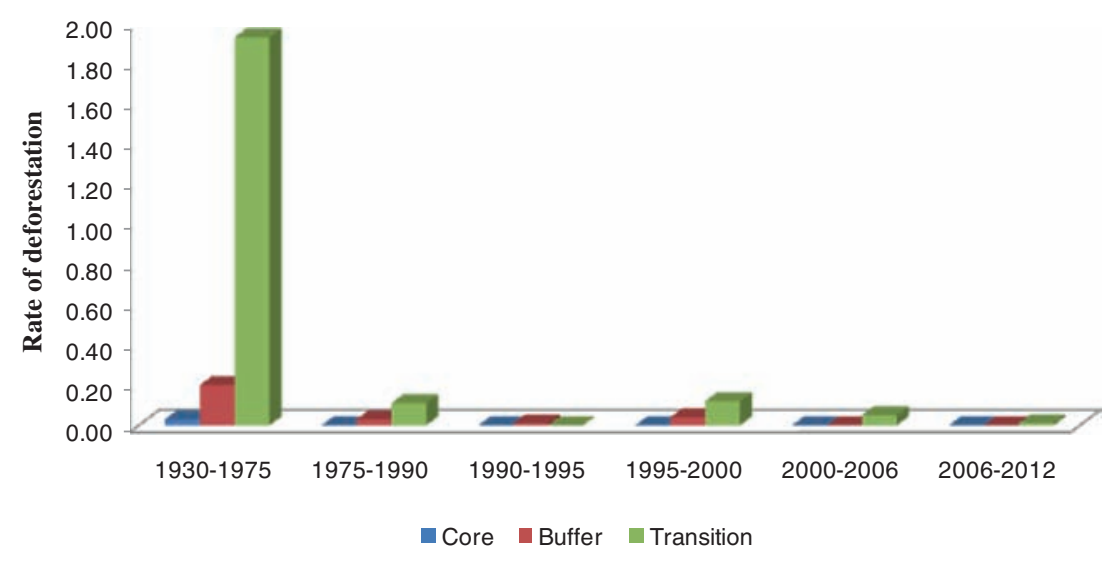

Figure 6. Graph showing net rate of deforestation in zones of Similipal Biosphere Reserve. 
Table 8. Conversion of Forest class to other land use from 1930 to 2012.

\begin{tabular}{llrr}
\hline Sl.no & Land use & Area $\left(\mathrm{km}^{2}\right)$ & \% of area \\
\hline 1 & Agriculture & 593.2 & 57.2 \\
2 & Scrub & 369.6 & 35.6 \\
3 & Water & 31.6 & 3.0 \\
4 & Orchards & 27.4 & 2.6 \\
5 & Settlements & 9.3 & 0.9 \\
6 & Grassland & 3.2 & 0.3 \\
7 & Barren land & 2.2 & 0.2 \\
8 & Mining & 1.4 & 0.1 \\
& Total & 1037.9 & 100.0 \\
\hline
\end{tabular}

forest to scrub, attributed to wood extraction. The major land use/land cover that has been converted from forest is represented in figure 7 .

High deforestation was observed in transition zone and low in parts of buffer zone of the reserve. Deforestation in southern part of Similipal was observed due to agricultural activities and logging. Badampahar, northwest region of Similipal is found to be a deforestation hotspot due to mining activities (figure 8). Similipal has experienced more deforestation due to human intervention within buffer and transition zones before declaration as biosphere reserve.

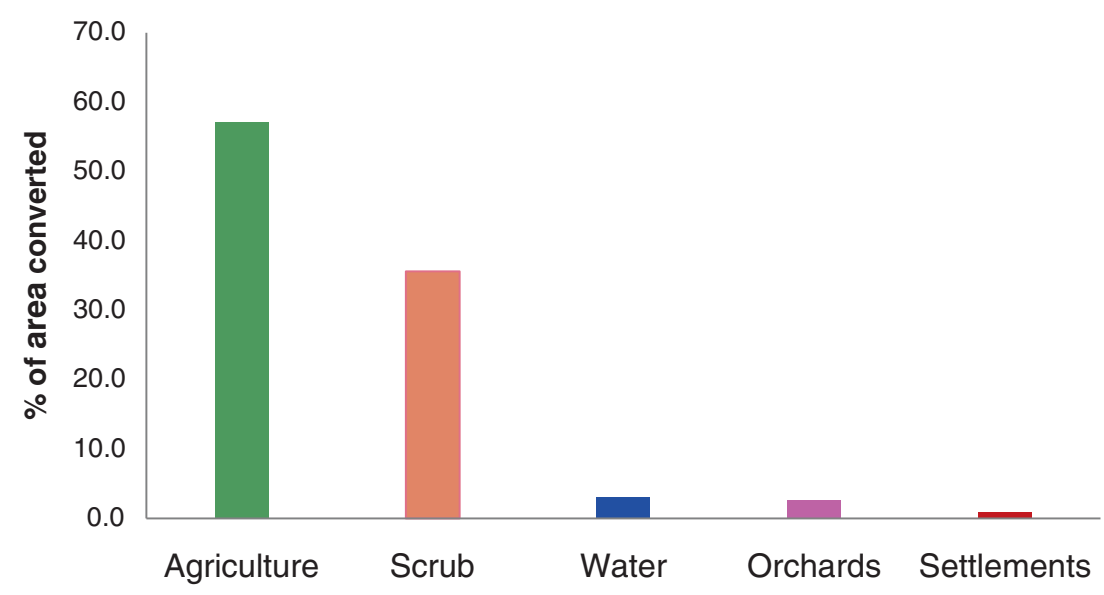

Figure 7. Major classes converted from forest during 1930 to 2012.
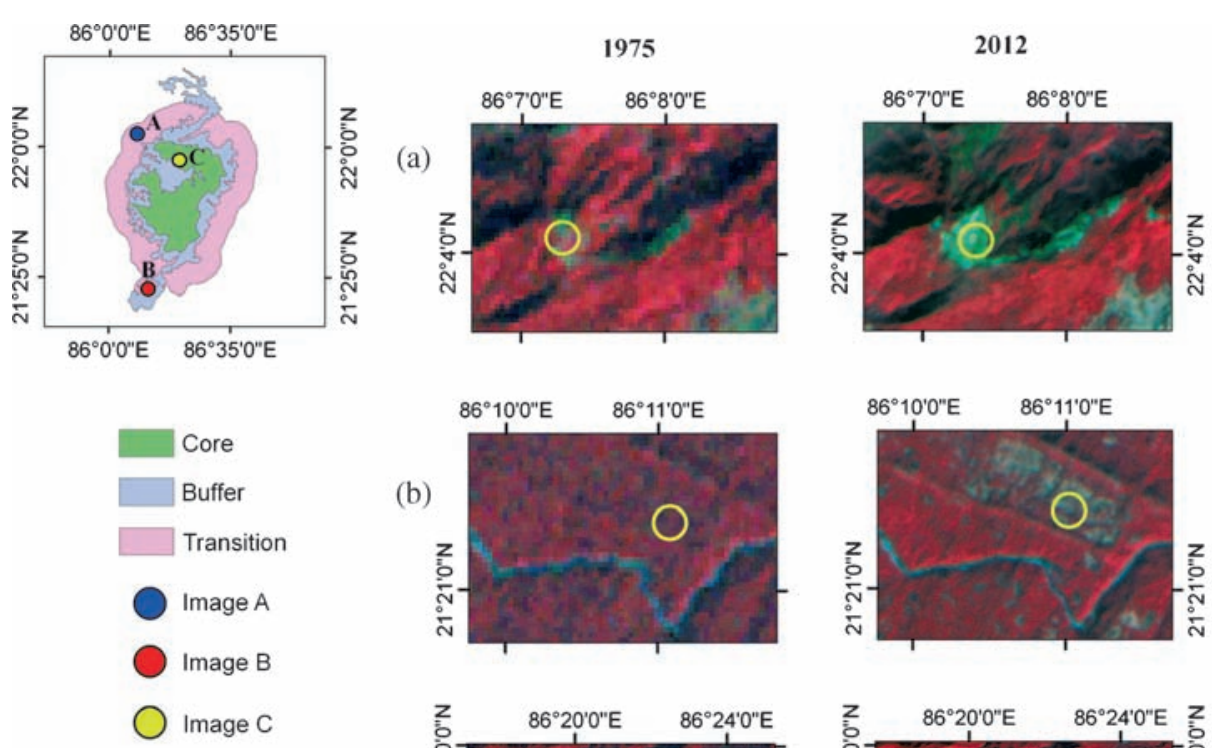

(b)
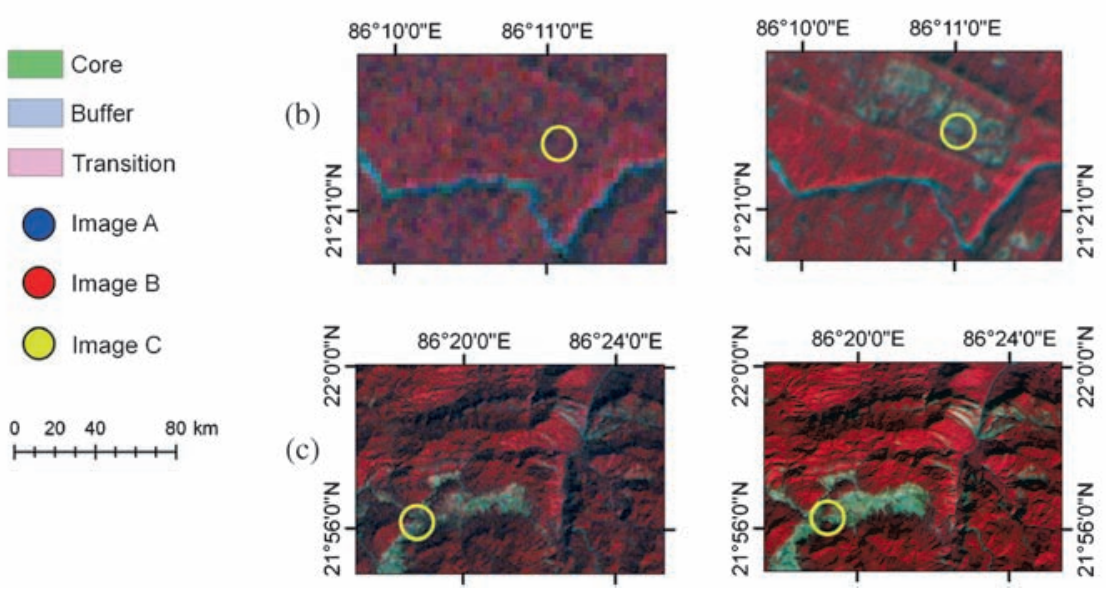

Figure 8. Landsat Multi Spectral Scanner (1975) and Resourcesat-2 LISS III (2012) False color composite image chips showing forest change (A) mining activities (greenish tone refers to mining) represents and (B \& C) agriculture expansion (whitish tone refers to agricultural fallow) in Similipal Biosphere reserve. 


\subsection{Change in forest types and land use}

Among the six forest types, semi-evergreen, moist deciduous, low level and, high level sal and riparian forests belong to the category of tropical moist forests, while dry deciduous forest belongs to tropical dry forest category (figure 9). The moist deciduous forest is the most predominant type in Similipal, which covered an area of $2033.7 \mathrm{~km}^{2}$ (64.8\% of forest cover and $36.5 \%$ of geographical area of Similipal Biosphere Reserve; table 9) followed by dry deciduous forest and semi-evergreen forests occupying $9.9 \%$ and $4 \%$ of the forest area, respectively. Scrub has increased with transformation of forest cover due to exploitation of resources. A significant increase in the water bodies has been noticed due to construction of new dams after 1975, to support irrigation facility to agricultural fields.

As compared to Maya, Monarch Butterfly and Calakmul Biosphere Reserves, the Similipal Biosphere Reserve has been successful in protecting the forest cover (Sader et al. 2001; Chowdhury

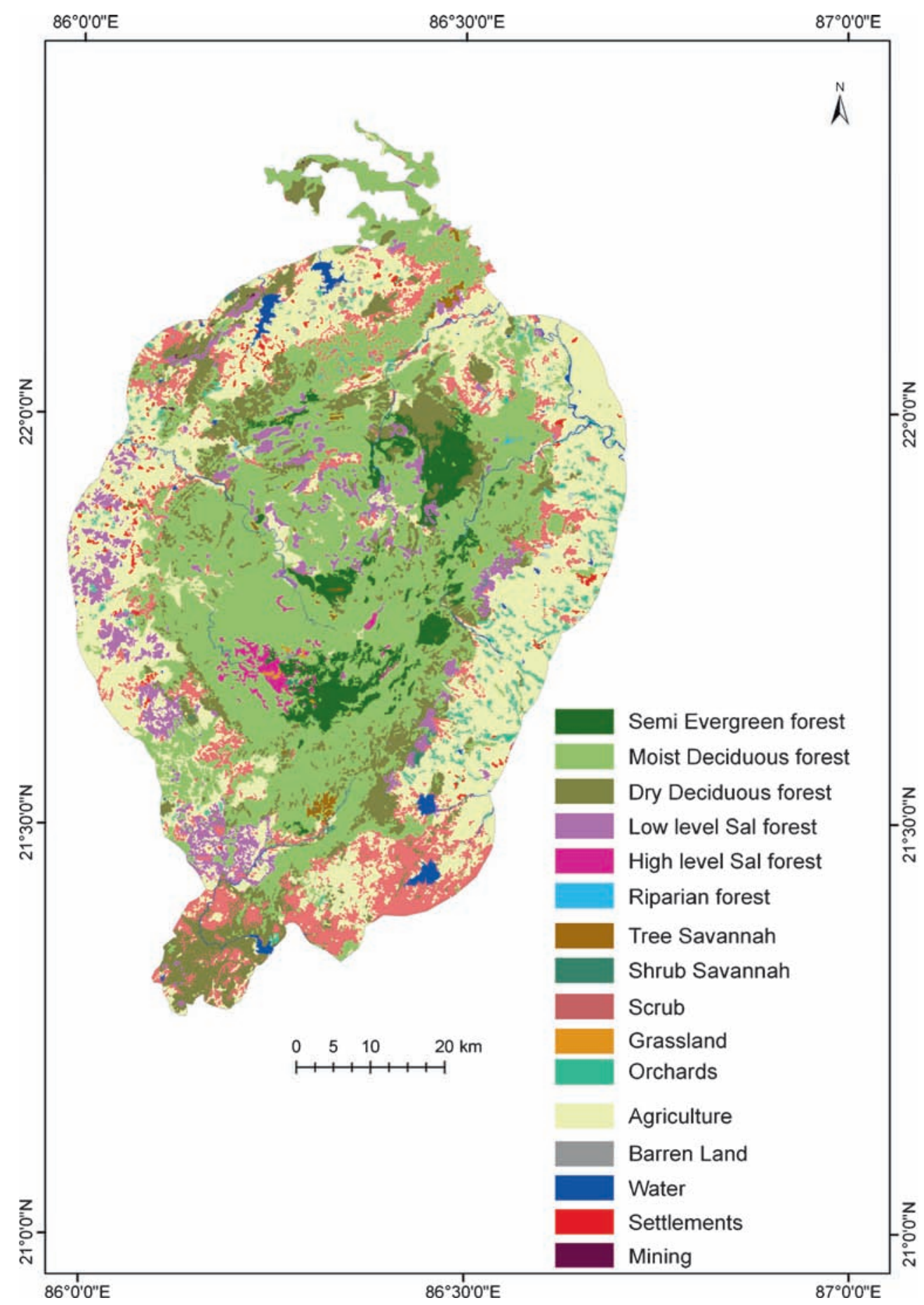

Figure 9. Classified map showing vegetation types and land use/land cover of Similipal Biosphere Reserve (2012). 
Table 9. Distribution of Forest types and other land cover in 1975 and 2012 (area in $\mathrm{km}^{2}$ ).

\begin{tabular}{|c|c|c|c|c|c|c|c|}
\hline \multirow[b]{2}{*}{ Sl. No. } & \multirow{2}{*}{$\begin{array}{c}\text { Forest type/ } \\
\text { land cover }\end{array}$} & \multicolumn{2}{|c|}{1975} & \multicolumn{2}{|c|}{2012} & \multicolumn{2}{|c|}{$\begin{array}{c}\text { Change } \\
(1975-2012)\end{array}$} \\
\hline & & Area $\left(\mathrm{km}^{2}\right)$ & $\%$ of area & Area $\left(\mathrm{km}^{2}\right)$ & $\%$ of area & & $\%$ of change \\
\hline 1 & Semi Evergreen forest & 224.1 & 4 & 223.9 & 4 & -0.2 & 0.1 \\
\hline 2 & Moist Deciduous forest & 2045.6 & 36.7 & 2033.7 & 36.5 & -11.9 & 0.6 \\
\hline 3 & Dry Deciduous forest & 565.7 & 10.2 & 549.7 & 9.9 & -16.1 & 2.8 \\
\hline 4 & Low Level Sal forest & 288.7 & 5.2 & 292.3 & 5.2 & 3.6 & 1.2 \\
\hline 5 & High Level Sal forest & 32.3 & 0.6 & 32.3 & 0.6 & 0 & 0 \\
\hline \multirow[t]{2}{*}{6} & Riparian forest & 3.3 & 0.1 & 3.2 & 0.1 & -0.1 & 4.2 \\
\hline & Sub-total & 3159.7 & 56.7 & 3135 & 56.3 & & \\
\hline 7 & Tree Savannah & 19.4 & 0.3 & 18.7 & 0.3 & -0.7 & 3.6 \\
\hline 8 & Shrub Savannah & 7.9 & 0.1 & 8.8 & 0.2 & -0.9 & 11.3 \\
\hline 9 & Scrub & 471.3 & 8.5 & 486 & 8.7 & 14.7 & 3.1 \\
\hline 10 & Grassland & 4 & 0.1 & 3.2 & 0.1 & -0.8 & 20.8 \\
\hline 11 & Orchards & 78.7 & 1.4 & 77.2 & 1.3 & -1.5 & 1.9 \\
\hline 12 & Agriculture & 1734.1 & 31.3 & 1736.2 & 31.1 & -2.1 & 0.1 \\
\hline 13 & Barren land & 11.6 & 0.2 & 12.2 & 0.2 & 0.6 & 4.9 \\
\hline 14 & Water & 45.8 & 0.8 & 63.9 & 1.1 & 18.1 & 39.5 \\
\hline 15 & Settlements & 26.9 & 0.5 & 28.6 & 0.5 & 1.7 & 6.1 \\
\hline \multirow[t]{3}{*}{16} & Mining & 0.1 & 0 & 1.4 & 0 & 1.3 & 93.1 \\
\hline & Sub-total & 2399.7 & 43.3 & 2433.8 & 43.7 & & \\
\hline & Total & 5559 & 100 & 5569 & 100 & & \\
\hline
\end{tabular}

2006; Garcia 2012). The study in Nilgiri Biosphere Reserve has shown no forest loss from 1999 onwards (Satish et al. 2014).

The major land use change drivers are agriculture expansion, excessive collection of non-timber forest products, logging and livestock grazing (Rout 2008). The study by Mishra (2010) had suggested reducing dependency of local people on forest products by providing alternate livelihood facilities, aids in eco-restoration and habitat improvement. Improving eco-developmental activities to meet the ecological demands and creating awareness on wildlife importance and education, mitigates the ecological imbalances in the study area.

\section{Conclusions}

This study on long term monitoring of forests illustrates the distribution, changes in forest cover and the rate of deforestation in Similipal Biosphere Reserve. The study shows declining trend of deforestation in biosphere reserve. The spatial framework used in the present study was found to be helpful in monitoring and quantification of forest cover (1930-1975, 1975-1990, 1990-1995, 1995-2000, 2000-2006 and 2006-2012). Therefore, this study helps in evaluating the spatial patterns of forests and prioritizes the landscapes for forest restoration and management activities. Local inhabitants should be involved in conservation programmes for long-term sustenance of biodiversity and biological resources. We hereby recommend use of very high resolution satellite data for holistic understanding of distribution of forest resources.

\section{Acknowledgements}

The present study has been carried out under the National project 'Inventorisation and Monitoring of Biosphere Reserves in India using Remote Sensing and GIS technology', supported by Ministry of Environment and Forests, Government of India. Authors are grateful to Dr V K Dadhwal, Director, NRSC and Dr C S Jha, Group Director, Forestry and Ecology Group, NRSC for facilities and encouragement. Authors are also thankful to Chief Wildlife Warden and Field Director, Similipal Biosphere Reserve and State Forest Department of Odisha for permission and support to carry out the field work.

\section{References}

Bahali D D, Agrawala D K and Chowdhery H J 1998 Similipal Tiger Reserve; In: Plant Diversity in Tiger Reserves of India (eds) Hajra P K, Gangopadhyay M and Chakraborty T, Botanical Survey of India, Kolkata, pp. 418-439.

Chowdhury R R 2006 Landscape change in the Calakmul Biosphere Reserve, Mexico: Modeling the driving forces 
of smallholder deforestation in land parcels; Appl. Geogr. 26 129-152.

FSI 2011 State of the forest report; Forest Survey of India, Ministry of Environment and Forests, Dehradun, India.

Garcia J L 2012 Deforestation and forest degradation in the Monarch Butterfly Biosphere Reserve, Mexico, 2003-2009; J. Maps 7(1) 626-633.

Gardner T A, Barlow J, Chazdon R, Ewers R M, Harvey C A, Peres C A and Sodhi N S 2009 Prospects for tropical forest biodiversity in a human-modified world; Ecology Lett. 12(6) 561-582.

Hansen M C, Stehman S V and Potapov P V 2010 Quantification of global gross forest cover loss; Proc. Natl. Acad. Sci. USA 107 8650-8655, http://glcf.umiacs.umd.edu.

Le Quéré C, Raupach M R, Canadell J G, Marland G, Bopp L, Ciais P, Conway T J, Doney S C, Feely R A, Foster P, Friedlingstein P, Gurney K, Houghton R A, House J I, Huntingford C, Levy P E, Lomas M R, Majkut J, Metzl N, Ometto J P, Peters G P, Prentice I C, Randerson J T, Running S W, Sarmiento J L, Schuster U, Sitch S, Takahashi T, Viovy N, van der Werf G R and Wood-ward F I 2009 Trends in the sources and sinks of carbon dioxide; Nat. Geosci. 2 831-836.

Mishra B K 2010 Conservation and management effectiveness of Similipal Biosphere Reserve, Orissa, India; Indian Forester 136(10) 1310.

Ohnesorge B, Plieninger T and Hostert P 2013 Management effectiveness and land cover change in dynamic cultural landscapes - assessing a Central European Biosphere Reserve; Ecol. Soc. 18(4) 23.

Palni L M S, Rawal R S, Rai R K and Reddy S V 2012 Compendium on Indian Biosphere Reserves - Progression during two decades of conservation; Uttarakhand: G.B. Pant Institute of Himalayan Environment and Development, Ministry of Environment and Forests, Government of India.

Puyravaud J P 2003 Standardizing the calculation of the annual rate of deforestation; For. Ecol. Manag. 177 593-596.

Reddy C S, Jha C S and Dadhwal V K 2013 Assessment and monitoring of long-term forest cover changes in Odisha,
India using remote sensing and GIS; Environ. Monit. Assess. 185 4399-4415.

Reddy C S, Jha C S, Dadhwal V K, Harikrishna P, Pasha S V, Satish K V, Dutta K, Saranya K R L, Rakesh F, Rajashekar G and Diwakar P G 2015 Quantification and monitoring of deforestation in India over eight decades (1930-2013); Biodivers. Conserv. 1-24, doi: 10.1007/ s10531-015-1033-2.

Reddy C S, Jha C S and Dadhwal V K 2016 Assessment and monitoring of long-term forest cover changes (1920-2013) in Western Ghats biodiversity hotspot; J. Earth Syst. Sci. 125(1) 103-114.

Romijn E, Ainembabazi J H, Wijaya A, Herold M, Angelsen A, Verchot L and Murdiyarso L 2013 Exploring different forest definitions and their impact on developing REDD+ reference emission levels: A case study for Indonesia; Environ. Sci. Policy 33 246-259.

Rout S D 2008 Anthropogenic threats and biodiversity conservation in Similipal Biosphere Reserve, Orissa, India; Tiger Paper 35(3) 22-26.

Sader S A, Hayes D J, Hepinstall J A, Coan M and Soza C 2001 Forest change monitoring of a remote biosphere reserve; Int. J. Remote Sens. 22 1937-1950.

Saranya K R L, Reddy C S, Prasada Rao P V V and Jha C S 2014 Decadal time scale monitoring of forest fires in Similipal Biosphere Reserve, India using Remote sensing and GIS; Environ. Monit. Assess. 186(5) 3283-3296.

Satish K V, Saranya K R L, Reddy C S, Krishna P H, Jha C S and Rao P P 2014 Geospatial assessment and monitoring of historical forest cover changes (19202012) in Nilgiri Biosphere Reserve, Western Ghats, India; Environ. Monit. Assess. 186(12) 8125-8140.

Saxena H O and Brahmam M 1989 The Flora of Similipahar, Orissa; Regional Research Laboratory, Bhubaneswar, India.

Schliep R and Stoll-Kleemann S 2010 Assessing governance of biosphere reserves in central Europe; Land Use Policy 27 917-927.

Secretariat of the Convention on Biological Diversity (SCBD) 2001 The value of forest ecosystems; SCBD, Montreal, Canada. 